NASA Technical Memorandum 106050

\title{
Space Chemical Propulsion Test Facilities at NASA Lewis Research Center
}

Donald C. Urasek and Frederick D. Calfo

Lewis Research Center

Cleveland, Ohio

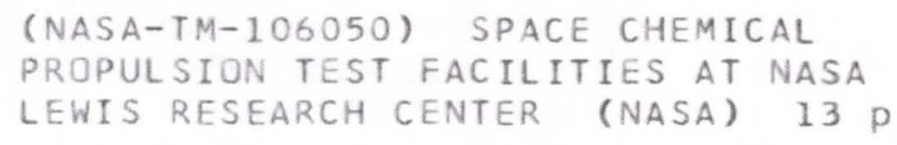

Prepared for the

Aerospace Atlantic Conference sponsored by the Society of Automotive Engineers

Dayton, Ohio, April 20-23, 1993 


\author{
Donald C. Urasek and Frederick D. Calfo \\ National Aeronautics and Space Administration \\ Lewis Research Center \\ Cleveland, Ohio 44135
}

\begin{abstract}
SUMMARY
The NASA Lewis Research Center, located in Cleveland, Ohio, has a number of space chemical propulsion test facilities which constitute a significant national space testing resource. The purpose of this paper is to make more users aware of these test facilities and to encourage their use through cooperative agreements between the government, industry, and universities. Research which is of interest to the government is especially encouraged and often can be done in a cooperative manner that best uses the resources of all parties.
\end{abstract}

This paper presents an overview of the Lewis test facilities. These facilities are clustered into three test areas: the Rocket Engine Test Facilities (RETF), the Rocket Laboratory (RL), and the Cryogenic Components Laboratory (CCL).

\title{
ROCKET ENGINE TEST FACILITIES (RETF)
}

The Rocket Engine Test Facility is a complex which contains the following test stands: (1) Sea-Level Rocket Engine Test Stand (A-stand), (2) Altitude Rocket Engine Test Stand (B-stand), and (3) Turbopump Test Stand (C-stand). Research programs are directed toward component testing of specific propulsion needs envisioned for future NASA missions. Programs include advanced thrust chamber heat transfer and cooling techniques, chamber life cycle testing, nozzle boundary layer predictions, combustion stability, and engine performance. To simplify the propellant feed complexities, the propellants are pressure fed to the engine.

An aerial photograph of the RETF is shown in figure 1 . The complex comprises six buildings and extensive on-site support services. One building houses the two rocket engine test stands and shop area. A second building houses the turbopump test stand. Small outlying buildings house helium compressors, a liquid hydrogen pump and vaporizer, and liquid nitrogen pumps and vaporizers. A control building from which all operations are handled is located approximately $1250 \mathrm{ft}$ from the test site.

The RETF contains pressurized propellant run tanks, propellant flow line systems, and a rocket exhaust gas treatment combination scrubber and silencing muffler. Located adjacent to the test cell area are 25 large-volume, high-pressure gas storage bottles, ranging in pressures from 4000 to 6000 psi. The support systems include permanent on-site bulk storage dewars for cryogenic liquid hydrogen, liquid oxygen, and liquid nitrogen, and a large water reservoir. The pressure and volume specifications of the pressure vessels, storage dewars, and water reservoir at RETF are shown in table I.

RETF has the flexibility for testing with cryogenic and Earth-storable propellants at high and low pressures. Liquid and gaseous hydrogen and oxygen, as well as liquid hydrocarbon, nitrogen tetroxide, and hydrazine propellants, have all been successfully tested at RETF. The following rocket test firings are performed: short duration $(0.3 \mathrm{sec})$, multiple pulses (3.0-sec duration), and single continuous long runs of up to 100 -sec duration. 
Sea-Level Rocket Engine Test Stand (A-Stand)

Test stand A is designed for sea-level testing of vertically mounted rocket engines discharging into an exhaust gas scrubber and muffler. The test stand can handle a wide variety of propellant combinations and can support propellant run tank pressure levels to 5000 psig and thrust levels to $50000 \mathrm{lb}$. Figure 2 shows A-stand with a mounted engine.

\section{Altitude Rocket Engine Test Stand (B-Stand)}

Test stand B is designed for altitude testing of horizontally mounted rocket engines exhausting into a diffuser, a cooler, and a two-stage ejector system. The test stand test-fires hydrogen-oxygen engines with thrust levels to $4000 \mathrm{lb}$ at simulated altitudes to $180000 \mathrm{ft}$. Figure 3 shows B-stand with a mounted engine.

\section{Turbopump Test Stand (C-Stand)}

Test stand $\mathbf{C}$ is designed for testing of cryogenic rocket engine turbopumps and turbopump components. Liquid hydrogen, liquid oxygen, and liquid nitrogen turbopumps and turbopump components can be driven with an assortment of high-pressure gases at ambient temperature. C-stand is shown in figure 4.

The operations at all three test stands are remotely controlled. Figure 5 shows an aerial photograph of the RETF control building. Programmable flow controllers and sequence timers provide automatic propellant flow control, remote sequence timing, and automatic permissive and cut-off control. Facility safety monitoring is also provided.

Data are recorded through a 200-channel, high-speed digitizer/multiplexer data acquisition system and fed through a direct digital data link to the Lewis Research Center central data system. The data are processed and then returned to the control room via hardcopy terminals and CRT's, thus providing on-line data reduction capabilities.

High-frequency-response analog data systems provide quick-look test data through oscillograph recorders. Low-frequency-response analog data are displayed on panel meters in the control room.

\section{ROCKET LABORATORY (RL)}

The Rocket Laboratory comprises 10 independent test facilities which perform basic research aimed at developing technologies for current and future space initiatives. Figure 6 shows an aerial photograph of the complex. The following facilities will be described here: (1) Low Thrust Propulsion Facility (Cell 11), (2) Low Thrust Rocket Facility (Cell 21), (3) High Heat Flux Thermal Shock Facility (Cell 22), and (4) Rocket Combustion Diagnostics Laboratory (Cell 32).

\section{Low Thrust Propulsion Facility (Cell 11)}

Hydrogen-oxygen thrusters are tested for performance and life in the Low Thrust Propulsion Facility (Cell 11), which is designed to test-fire rocket engines at altitude conditions and thrust levels to $50 \mathrm{lb}$. 
This facility is capable of long-duration test firings at simulated altitudes to $120000 \mathrm{ft}$. Cell 11 is shown in figure 7.

The propellants are supplied from gaseous hydrogen and gaseous oxygen tube trailers of 70000 and $50000 \mathrm{SCF}$ capacity, respectively. The maximum flow rate of the gaseous hydrogen is $0.022 \mathrm{pps}$ at $1200 \mathrm{psi}$, and the maximum flow rate of the gaseous oxygen is $0.08 \mathrm{pps}$ at $1000 \mathrm{psi}$. Air-driven ejectors are used to evacuate the vacuum tank. Test operations are remotely controlled with a programmable logic controller (PLC). The data system can record up to 2500 samples of data per second. A laser is used to perform nonintrusive studies of the rocket engine exhaust plumes.

\section{Low Thrust Rocket Facility (Cell 21)}

At the Low Thrust Rocket Facility (Cell 21), research activities include multi-compartment ignition techniques and in situ propellant and metallized propellant performance testing. The facility can be operated at either atmospheric or altitude exhaust conditions at thrust levels up to $100 \mathrm{lb}$. Cell 21 is shown in figure 8.

Gaseous hydrogen, gaseous methane, gaseous carbon monoxide, RP-1, liquid propane, and metallized propellants can be supplied to the facility. Gaseous oxygen is used as the oxidizer for all testing. A $50000 \mathrm{SCF}$ gaseous oxygen tube trailer supplies oxygen at a maximum flow rate of $0.10 \mathrm{pps}$ at $1500 \mathrm{psig}$. Gaseous methane and carbon monoxide are supplied into a manifold system from K-bottle cylinders. The K-bottle capacity is $1200 \mathrm{SCF}$ at pressures up to 1600 psig. Liquid fuel is supplied from eight 1-gal tanks with working pressures to $1500 \mathrm{psig}$. Metallized propellant fuels are fed to the cell at pressures to 1250 psig. Air-driven ejectors provide altitude capabilities.

A programmable logic controller is used to sequence valve operations. Data capabilities include a high-speed data acquisition system (100 channels) with an overall digitizing rate of 50000 samples per second and a low-speed data acquisition system (111 channels) with a digitizing rate of approximately 80 samples per second.

\section{High Heat Flux Thermal Shock Facility (Cell 22)}

At the High Heat Flux Thermal Shock Facility (Cell 22), research is conducted on ceramic composites, transpiration-cooled seals, thin film thermocouples, and leading edge erosion and oxidation. A 1000-lb-thrust gaseous hydrogen/gaseous oxygen rocket engine is used as a workhorse for testing specimens mounted in the rocket engine exhaust plume. The samples are subjected to temperatures to $5500^{\circ} \mathrm{F}$. The data acquisition systems described for Cell 21 are shared with Cell 22. A programmable logic controller is used to control the test operations. The facility is shown in figure 9.

\section{Rocket Combustion Diagnostics Laboratory (Cell 32)}

The Rocket Combustion Diagnostics Laboratory (Cell 32) is shown in figure 10. The cell is currently under construction and will be completed by mid-1993. The facility will initially be used to verify combustion stability models.

The cell is designed for test-firing gaseous hydrogen/liquid oxygen or gaseous hydrogen/gaseous oxygen rocket engines at thrust levels to $2000 \mathrm{lb}$ for short-duration performance characterizations. The 
propellants systems are supplied from gaseous hydrogen and gaseous oxygen tube trailers of 70000 and 50000 SCF capacity, respectively. Liquid oxygen will be supplied from a 50-gal tank with a working pressure of 1800 psig.

Data capabilities include a high-speed data acquisition system (150 channels) with an overall digitizing rate of 600000 samples per second and a low-speed data acquisition system (111 channels) with a record rate of approximately 80 samples per second. A programmable logic controller is used to control the test operations.

Several ports for optical access are located in the main blast wall which separates the test cell from the laser room. This arrangement will allow the use of laser diagnostic equipment to study complex flow phenomena. A phase Doppler droplet analyzer (PDDA) will measure injector spray droplet size and study velocity characteristics. A laser Doppler velocimeter (LDV) will measure the velocity of droplets and particles in the flow stream. A copper vapor laser flow visualization system will provide qualitative and quantitative flow data. A laser spectroscopy system is planned for the future.

\section{CRYOGENIC COMPONENTS LABORATORY (CCL)}

The Cryogenic Components Laboratory is a complex of five small test facilities surrounding a centrally located control building. The complex (fig. 11) is designed for hazardous test operations, with each of the buildings separated by earthen blast mounds. Gaseous nitrogen and gaseous helium at working pressures of $2400 \mathrm{psi}$, along with air at $120 \mathrm{psi}$, are fed to each of the test cells through centralized manifold systems. Gaseous nitrogen is supplied from 250000 SCF bottles at flow rates to 2000 SCFM. Gaseous helium is supplied from a 70000 SCF tube trailer at flow rates to 2000 SCFM. Low-speed data acquisition systems, with sampling rates of 1 sample per second per channel, support each test cell.

In cell 1 , a $225-\mathrm{ft}^{2}$ building, research programs are conducted on the performance and life testing of liquid oxygen and liquid nitrogen bearings and seals. The building has a dedicated 3000-gal run tank with a working pressure of $250 \mathrm{psi}$. A cryogenic pump, rated at $75 \mathrm{gal} / \mathrm{min}$ and $1500 \mathrm{psig}$, supplies the fluid to the testers.

Cell 2 is also $225 \mathrm{ft}^{2}$. Research programs include the performance of small liquid hydrogen pumps and health monitoring code predictions for bearings and seals. The facility has a dedicated 1300-gal liquid hydrogen vacuum-jacketed run tank rated for $1400 \mathrm{psig}$. Gaseous hydrogen, for driving the turbine and pressurizing the run tank, is supplied from two 70000 SCF tube trailers.

Cell 4 is being reconfigured for fundamental experiments on rocket turbopumps. The building will be enlarged to $1500 \mathrm{ft}^{2}$ and will house a closed-loop water tunnel. The tunnel will be used to test and evaluate the sensitivity of pump design parameters with stall characteristics. The water pump will be driven with a 600-hp electric motor and gear box drive system.

Cell 5 is a $400-\mathrm{ft}^{2}$ building which is configured for handling high-pressure liquid and gaseous hydrogen fundamental experiments. The current program is the evaluation of catalysts for converting from para-toortho hydrogen. The facility has a dedicated 560 -gal liquid hydrogen vacuum-jacketed run tank with a working pressure of 1400 psig. Gaseous hydrogen is supplied to the facility from a 70000 SCF tube trailer.

Cell 7 is a $225-\mathrm{ft}^{2}$ building which is configured to handle small liquid hydrogen and liquid nitrogen fundamental experiments. Research has been focused on nonventing cryogen transfer experiments. The 
test cell has no permanent cryogenic supply systems. The experiments depend on roadable dewars as required.

\section{CONCLUDING REMARKS}

NASA encourages cooperative activities involving industry, universities, and other government agencies in areas of mutual interest. The facilities described provide a broad capability that can be applied to research and development in many technical areas. Persons interested in pursuing joint activities or using these facilities should contact the chief of the Space Propulsion Technology Division, Dr. Larry A. Diehl, at 216-977-7505.

\section{TABLE I.-PRESSURE AND VOLUME SPECIFICATIONS FOR \\ PRESSURE VESSELS, STORAGE DEWARS, AND WATER}

RESERVOIR AT THE ROCKET ENGINE

\begin{tabular}{|c|c|c|}
\hline & Volume & $\begin{array}{c}\text { Maximum } \\
\text { working } \\
\text { pressure, } \\
\text { psig }\end{array}$ \\
\hline Liquid hydrogen run tanks & $\begin{array}{l}1300 \mathrm{gal} \\
1000 \mathrm{gal}\end{array}$ & $\begin{array}{l}1500 \\
5000\end{array}$ \\
\hline Liquid oxygen run tanks & $\begin{array}{l}400 \mathrm{gal} \\
400 \mathrm{gal}\end{array}$ & $\begin{array}{l}1500 \\
5000\end{array}$ \\
\hline Water tanks & $\begin{array}{r}1300 \mathrm{gal} \\
600 \mathrm{gal}\end{array}$ & $\begin{array}{l}1500 \\
5000\end{array}$ \\
\hline Hydrocarbon run tank & $600 \mathrm{gal}$ & 5000 \\
\hline Gaseous hydrogen high-pressure bottles & $390000 \mathrm{SCF}$ & 4000 \\
\hline Gaseous oxygen tuber & $70000 \mathrm{SCF}$ & 2400 \\
\hline Gaseous helium high-pressure bottles & $160000 \mathrm{SCF}$ & 4000 \\
\hline Gaseous helium high-pressure bottle & $100000 \mathrm{SCF}$ & 6000 \\
\hline $\begin{array}{l}\text { General-usage high-pressure bottles for gaseous } \\
\text { hydrogen, helium, and nitrogen }\end{array}$ & $290000 \mathrm{SCF}$ & 6000 \\
\hline Water reservoir & $500000 \mathrm{gal}$ & $\ldots$ \\
\hline Liquid hydrogen storage dewar & $19000 \mathrm{gal}$ & 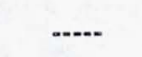 \\
\hline Liquid nitrogen storage dewar & $28000 \mathrm{gal}$ & $\cdots$ \\
\hline
\end{tabular}




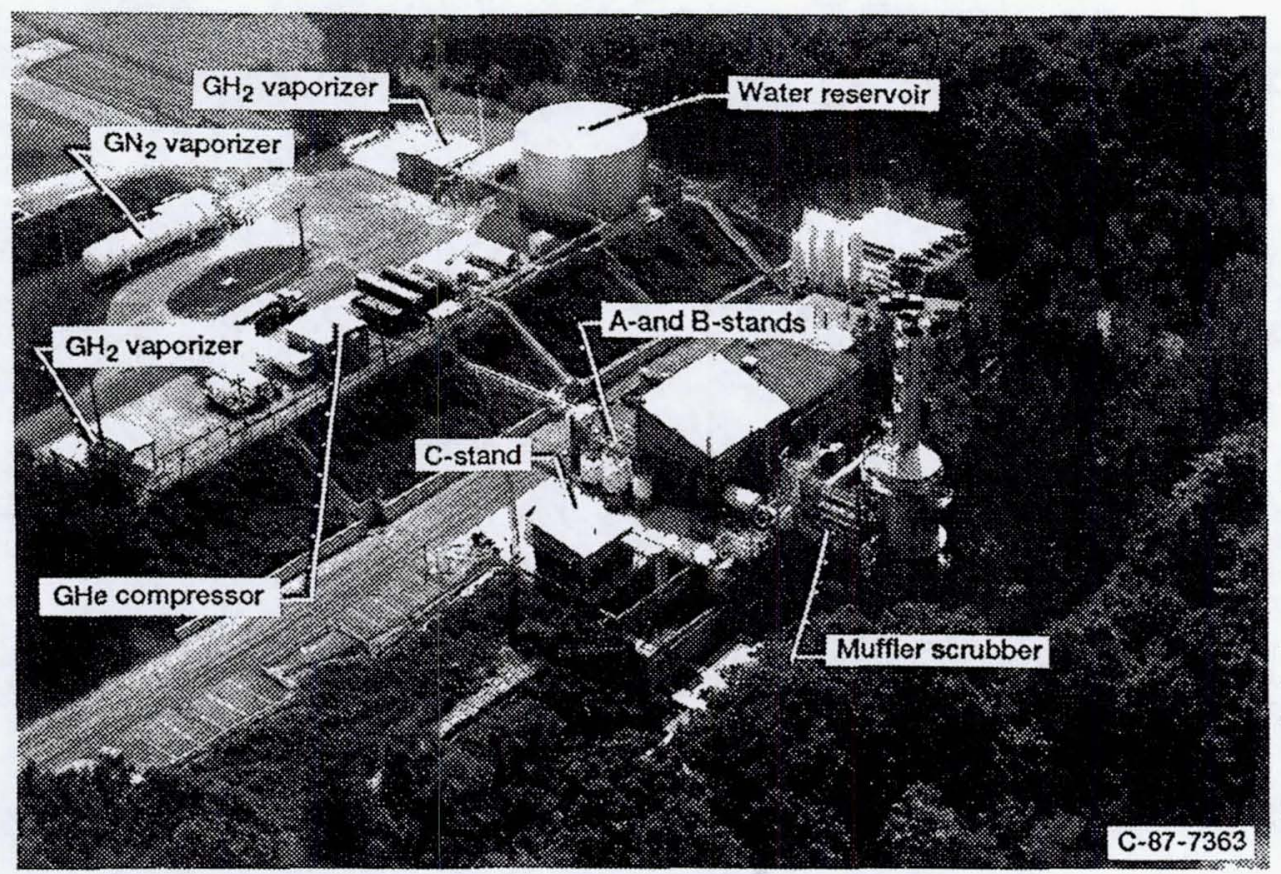

Figure 1.-Rocket Engine Test Facilities (RETF) complex.

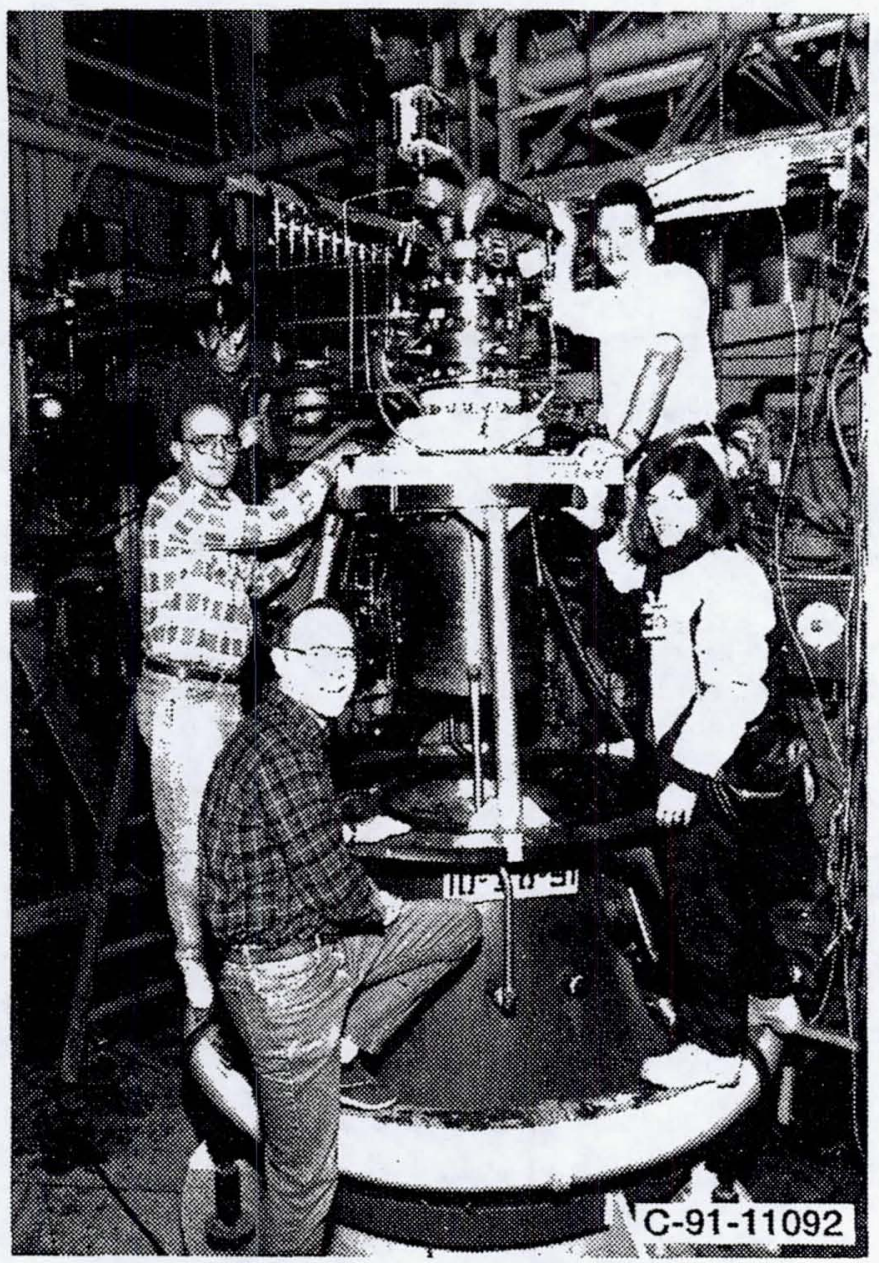

Figure 2.-Engine mounted on A-stand. 


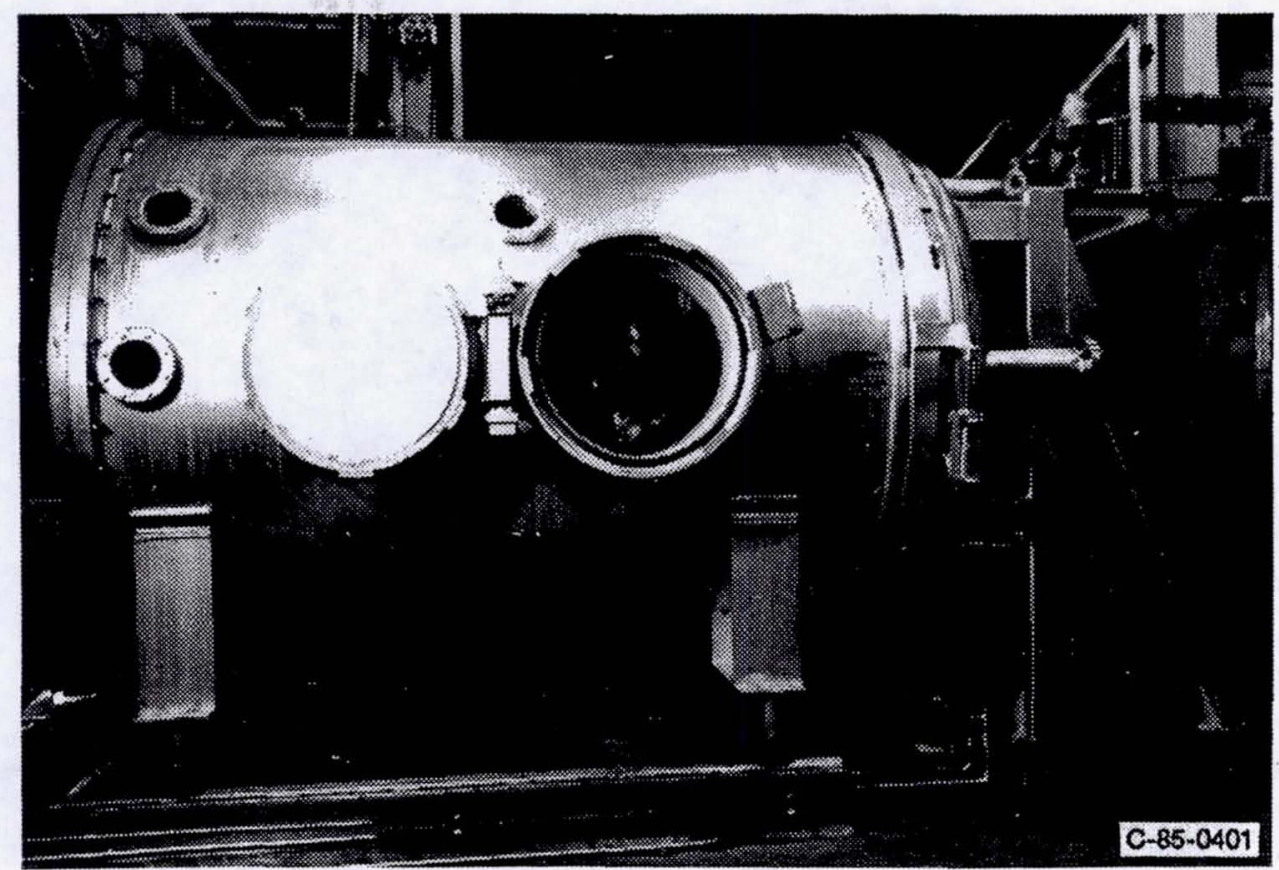

Figure 3.-Engine mounted on B-stand.

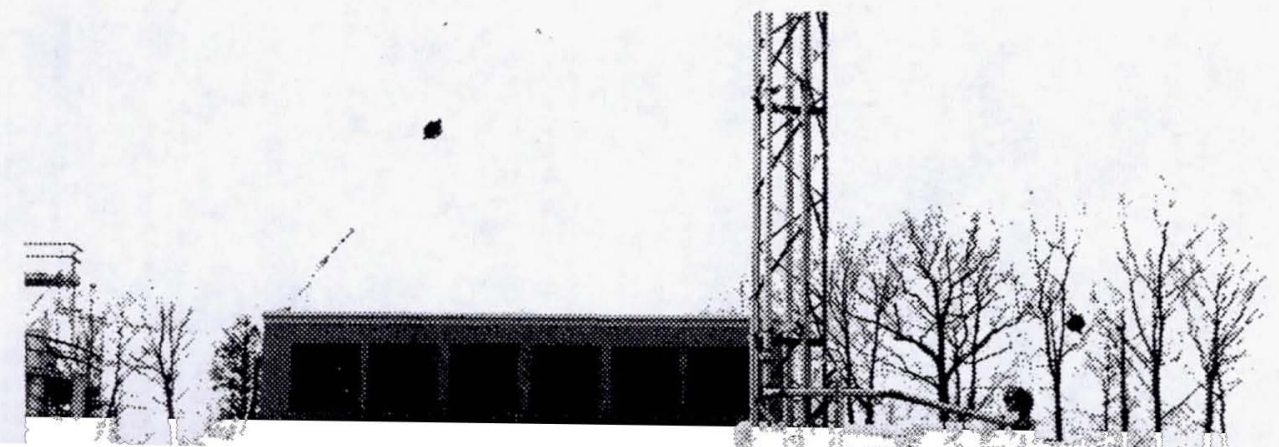




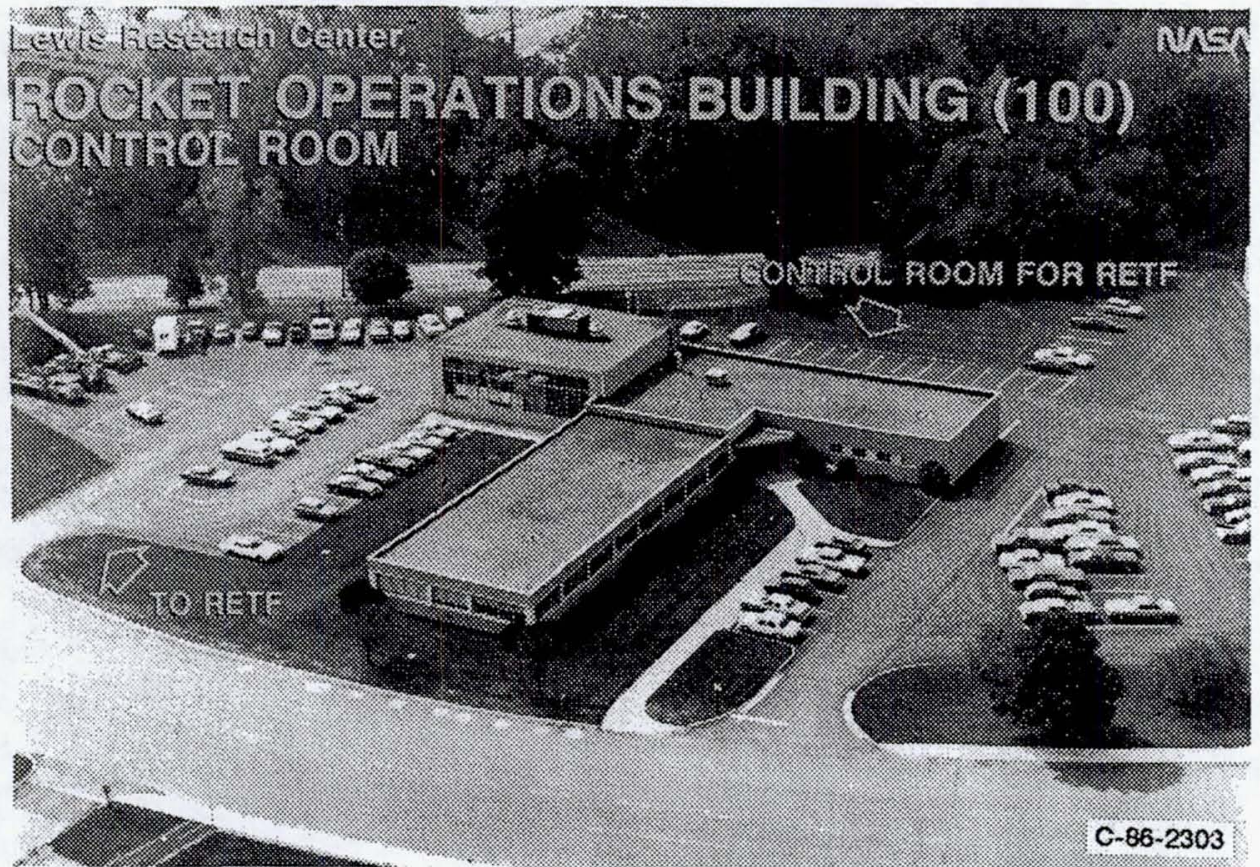

Figure 5.-Control building.

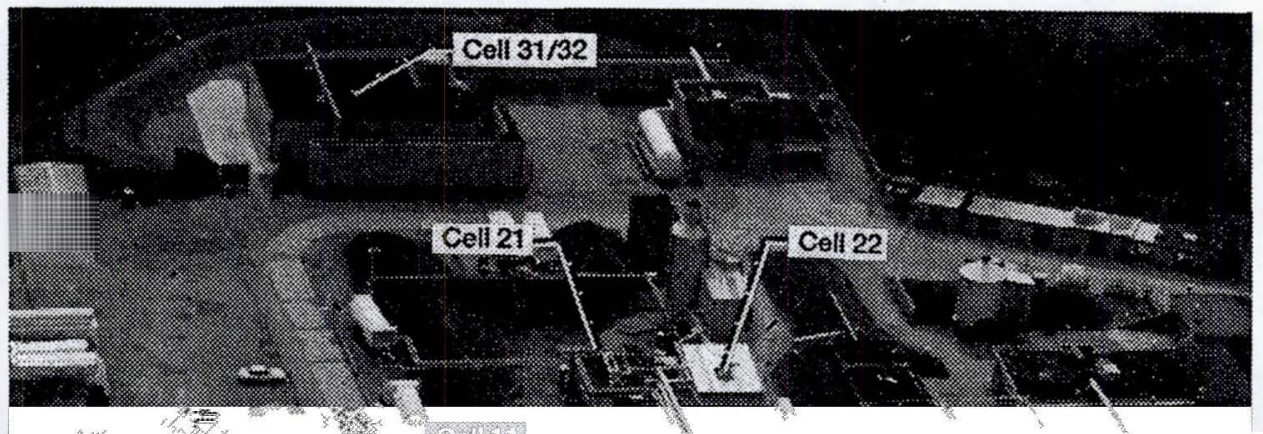




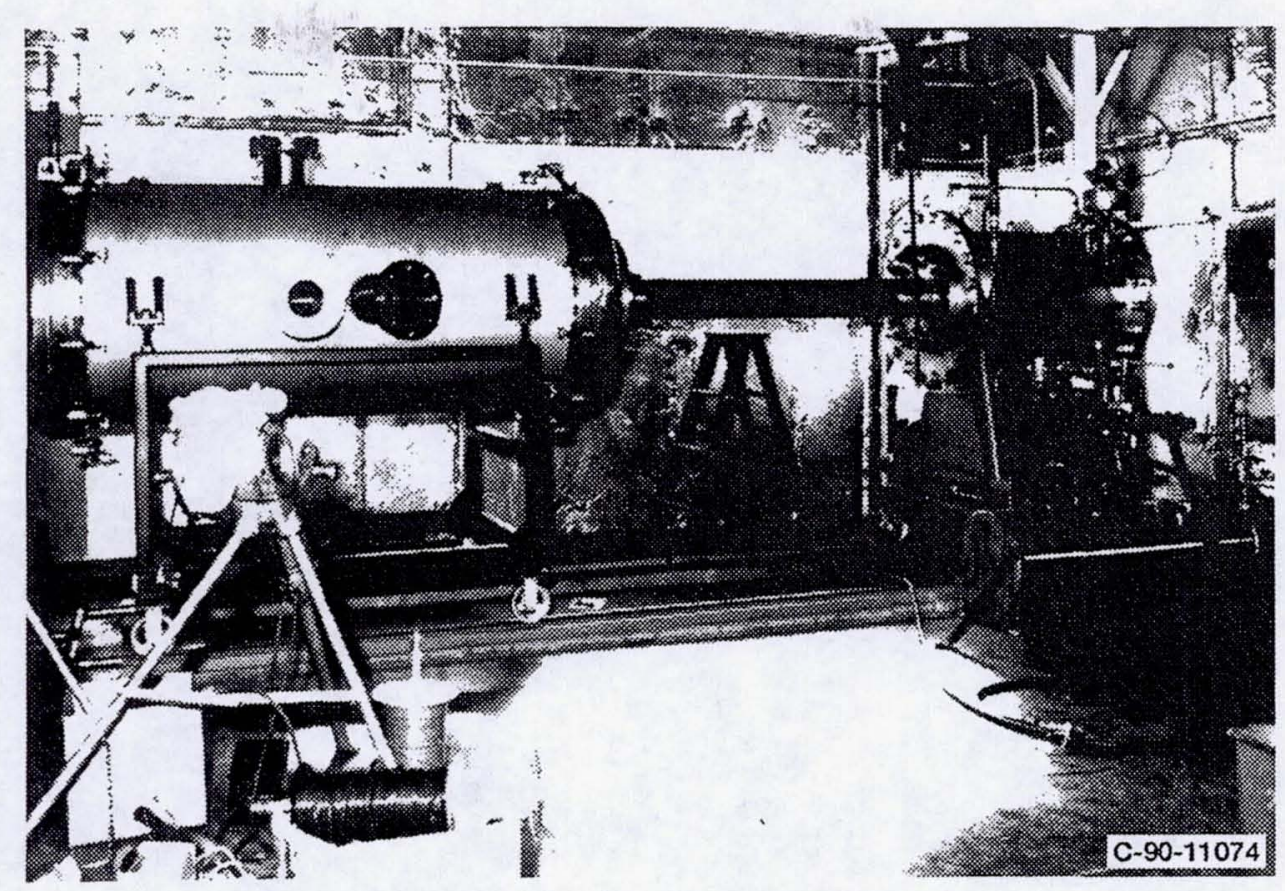

Figure 7.-Low Thrust Propulsion Facility (Cell 11).

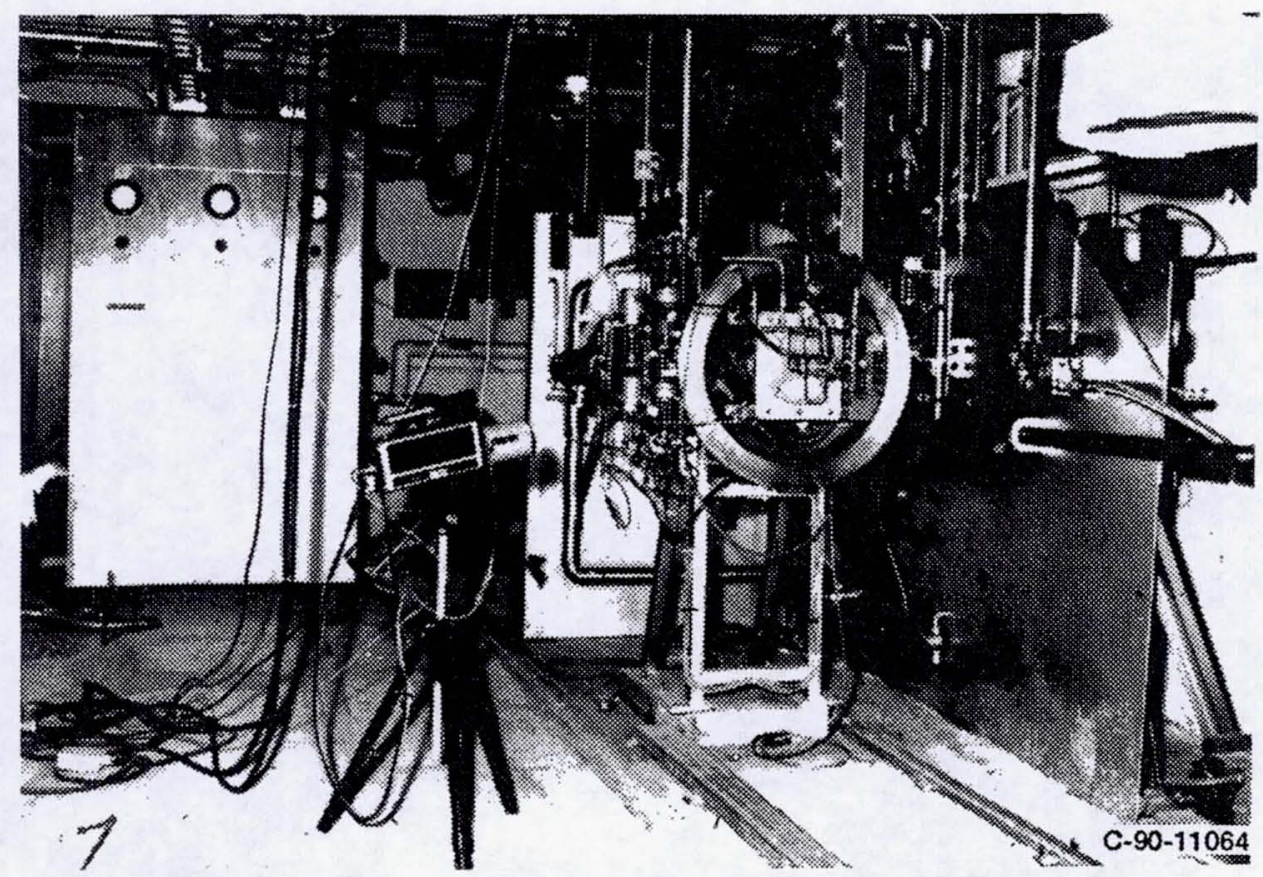

Figure 8. - Low Thrust Rocket Facility (Cell 21). 


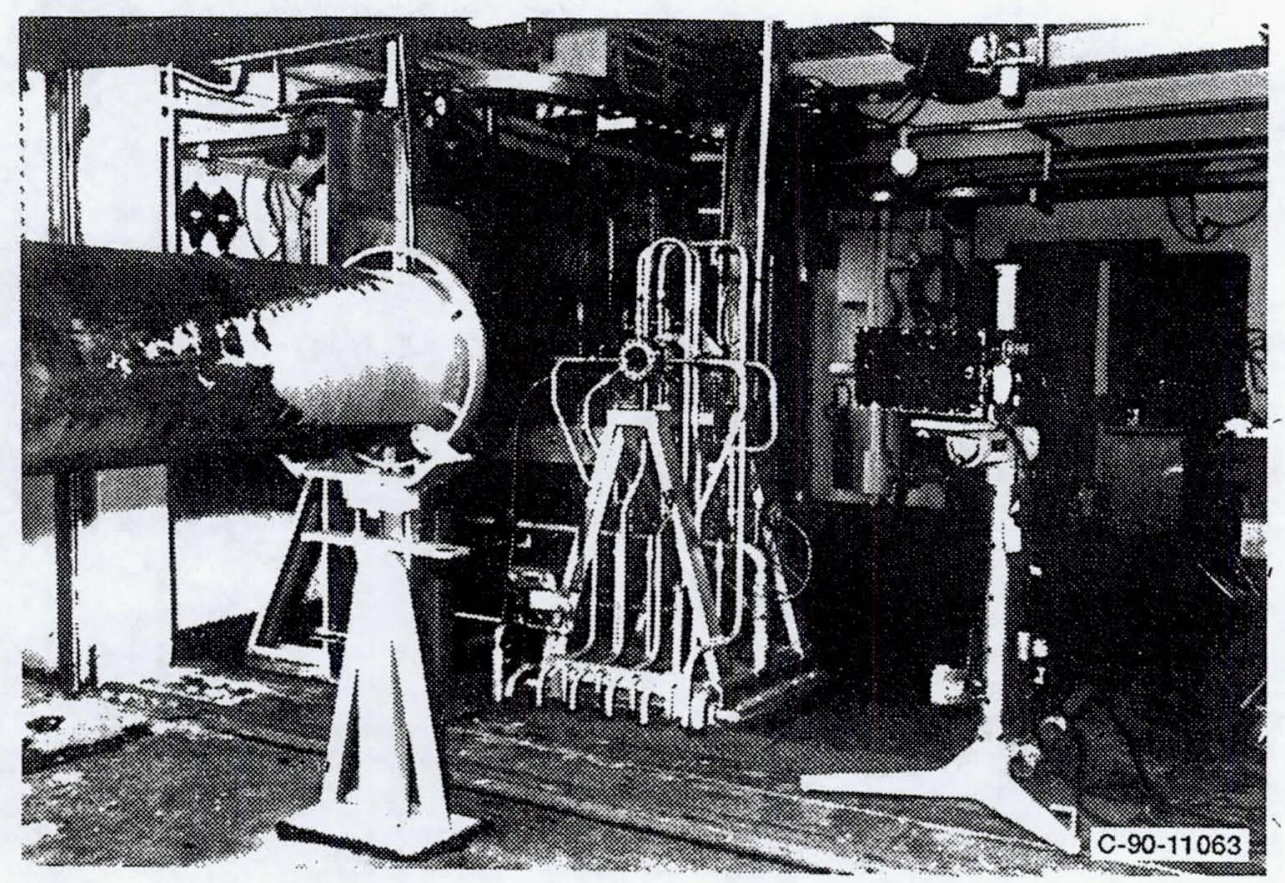

Figure 9.-High Heat Flux Thermal Shock Facility (Cell 22).

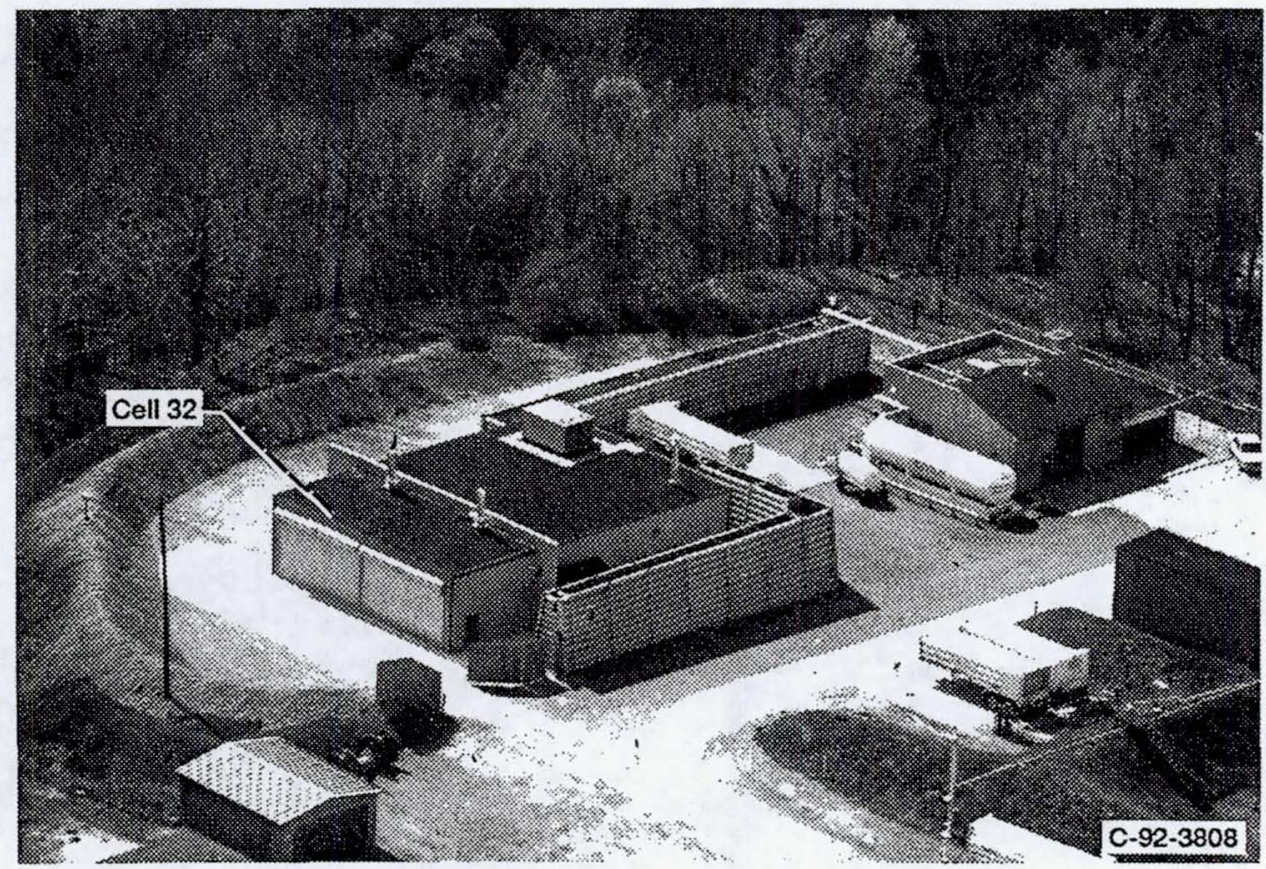

Figure 10.-Rocket Combustion Diagnostics Laboratory (Cell 32). 


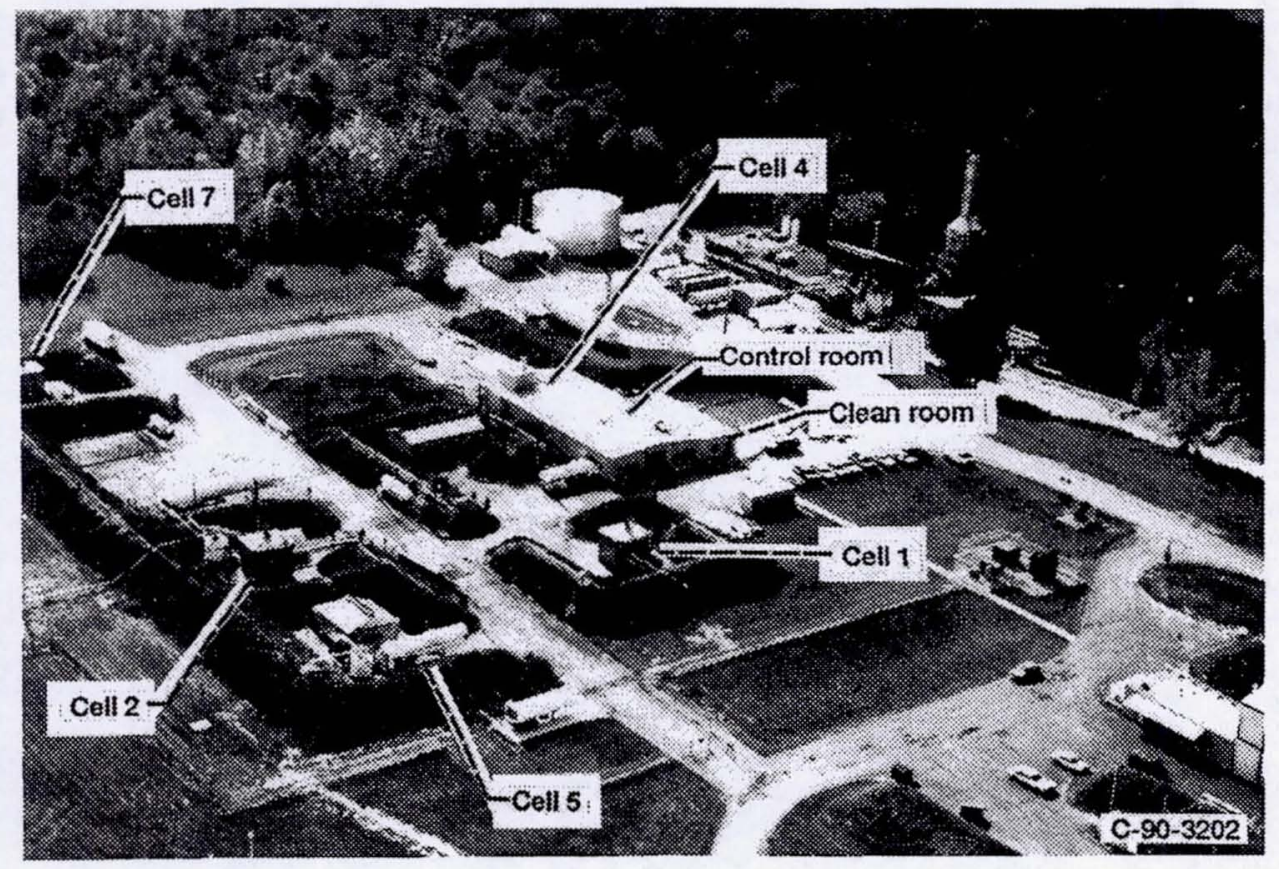

Figure 11.-Cryogenic Components Laboratory complex. 


\section{REPORT DOCUMENTATION PAGE}

Public reporting burden for this collection of information is estimated to average 1 hour per response, including the time for reviewing instructions, searching existing data sources, gathering and maintaining the data needed, and completing and reviewing the collection of information. Send comments regarding this burden estimate or any other aspect of this collection of information, including suggestions for reducing this burden, to Washington. Headquarters Services, Directorate for information Operations and Reports, 1215 Jefferson Davis Highway, Suite 1204, Arlington, VA 22202-4302, and to the Office of Management and Budget, Paperwork Reduction Project (0704-0188), Washington, DC 20503.

\begin{tabular}{l|l|r|} 
1. AGENCY USE ONLY (Leave blank) & $\begin{array}{c}\text { 2. REPORT DATE } \\
\text { April } 1993\end{array}$ & $\begin{array}{r}\text { 3. REPORT TYPE AND DATES COVERED } \\
\text { Technical Memorandum }\end{array}$
\end{tabular}

4. TITLE AND SUBTITLE

5. FUNDING NUMBERS

Space Chemical Propulsion Test Facilities at NASA Lewis Research Center

6. AUTHOR(S)

WU-584-03-11

Donald C. Urasek and Frederick D. Calfo

7. PERFORMING ORGANIZATION NAME(S) AND ADDRESS(ES)

8. PERFORMING ORGANIZATION REPORT NUMBER

National Aeronautics and Space Administration

Lewis Research Center

Cleveland, Ohio 44135-3191

E-7640

9. SPONSORING/MONITORING AGENCY NAMES(S) AND ADDRESS(ES)

10. SPONSORING/MONITORING AGENCY REPORT NUMBER

National Aeronautics and Space Administration

Washington, D.C. 20546-0001

NASA TM-106050

11. SUPPLEMENTARY NOTES

Prepared for the Aerospace Atlantic Conference sponsored by the Society of Automotive Engineers, Dayton, Ohio, April 20-23, 1993. Donald C. Urasek and Frederick D. Calfo, NASA Lewis Research Center. Responsible person, Donald C. Urasek, (216) 433-7566.

\begin{tabular}{|l|l|l} 
12a. DISTRIBUTION/AVAILABILITY STATEMENT & 12b. DISTRIBUTION CODE
\end{tabular}

Unclassified - Unlimited

Subject Category

13. ABSTRACT (Maximum 200 words)

The NASA Lewis Research Center, located in Cleveland, Ohio, has a number of space chemical propulsion test facilities which constitute a significant national space testing resource. The purpose of this paper is to make more users aware of these test facilities and to encourage their use through cooperative agreements between the government, industry, and universities. Research which is of interest to the government is especially encouraged and often can be done in a cooperative manner that best uses the resources of all parties. This paper presents an overview of the Lewis test facilities.

14. SUBJECT TERMS

Space chemical propulsion; Rocket engine test facilities

SEURITY CLASSIFICATION OF REPORT

Unclassified
18. SECURITY CLASSIFICATION OF THIS PAGE

Unclassified
19. SECURITY CLASSIFICATION OF ABSTRACT Unclassified 